\title{
Histone purification from Saccharomyces cerevisiae
}

\author{
Frederic Jourquin and Vincent Géli
}

Cancer Research Center of Marseille (CRCM), U1068 Inserm, UMR7258 CNRS, Aix Marseille University (AMU), Institut Paoli-Calmettes. Marseille, F-13009. France.

\begin{abstract}
Summary
The nucleosome structure consists of a histone octamer made by a tetramer of $\mathrm{H} 3-\mathrm{H} 4$ histones and two dimers of H2A-H2B. Nucleosomes undergo extensive posttranslational modifications that regulate nucleosome interactions, position, and stability. We describe a protocol allowing the robust purification of histones from the yeast Saccharomyces cerevisiae. This method appears to be suitable to quantitatively analyse specific posttranslational histone modifications.
\end{abstract}

Key words : Histones, chromatin, purification, budding yeast

\section{Introduction}

This protocol to purify yeast histones by acid extraction of isolated chromatin is adapted from Dehe et al (2005) and Poveda et al (2004). The protocol is written for an amount of wet yeast cells of $100 \mathrm{mg}$. It can be adapted for larger amount of wet cells.

\section{Materials}

All solutions are prepared using ultrapure water (prepared from deionized water to reach the $18,2 \mathrm{M} \Omega \mathrm{cm}$ at $25^{\circ} \mathrm{C}$ )

1. YPD:XXX

2. Buffer 1 (extraction buffer $\mathrm{pH}=7,5$ ) : $1 \mathrm{M}$ sorbitol, $50 \mathrm{mM}$ Tris- $\mathrm{HCl} \mathrm{pH}=7,5,5 \mathrm{mM}$ $\mathrm{MgCl}_{2}$ (keep at $-20^{\circ} \mathrm{C}$ )

3. Buffer 2 (extraction buffer $\mathrm{pH}=6$ ) : $1 \mathrm{M}$ sorbitol, $50 \mathrm{mM}$ MES $\mathrm{pH}=6,5 \mathrm{mM} \mathrm{MgCl} 2$ (buffered with $\mathrm{KOH} 2 \mathrm{M}$ and keep at $-20^{\circ} \mathrm{C}$ )

4. Buffer 3 (lysis buffer $\mathrm{K}$ ) : $50 \mathrm{mM}$ MES pH=6, $75 \mathrm{mM} \mathrm{KCl}, 0,5 \mathrm{mM} \mathrm{CaCl} 2,0,1 \% \mathrm{NP}-$ 40 (keep at $-20^{\circ} \mathrm{C}$ )

5. Buffer 4 (lysis buffer HS) : $10 \mathrm{mM} \mathrm{MES} \mathrm{pH=6,} 430 \mathrm{mM} \mathrm{NaCl}$ (keep at $4^{\circ} \mathrm{C}$ )

6. PI (Protease Inhibitors). For a $20 \mathrm{ml}$ solution: $400 \mu \mathrm{l}$ of PI complete mini EDTAFree (Roche), $20 \mu \mathrm{l}$ of 20mM 3-4 Dichloroisocoumarin serine protease inhibitor (Sigma Aldrich), $40 \mu \mathrm{l}$ of PMSF 0,5 M (prepared in DMSO solution) 
7. Zymolyase (R) 20T from Arthrobacter luteus

8. 2-mercaptoethanol (14.3M)

9. IGEPAL ${ }^{\circledR}$ CA-630 detergent (Nonidet $\mathrm{P}-40$ substitute)

10. $0.25 \mathrm{M} \mathrm{HCl}$

11. Acetone

12. Acidified acetone: $120 \mathrm{mM} \mathrm{HCl}$ in acetone

13. loading buffer (2X):xxx

14. Coomassie staining : $50 \%$ ethanol, $7 \%$ acid acetic, $0,5 \mathrm{~g} / \mathrm{L}$ Coomassie brilliant blue R250. Complete to $1 \mathrm{~L}$ with distilled water. Store at room temperature.

15. Coomassie Destaining : $20 \%$ ethanol ; $7 \%$ acid acetic. Store at room temperature.

\section{Methods}

3.1 Cell sample preparation

1. Inoculate $100 \mathrm{ml}$ YPD with a wild type strain (W303) (See note 1) to an $\mathrm{OD}_{600}$ below 0,1 . Grow the culture at $30^{\circ} \mathrm{C}$

2. Harvest the cells at $\mathrm{OD}_{600}=0,8$ and centrifuge the culture for $5 \mathrm{~min}$ at $3000 \mathrm{rpm}$

3. Wash the cell pellet twice in water

4. Wash the cell pellet with buffer 1

5. Weight the cellular pellet

6. Prepare samples of $100 \mathrm{mg}$ of wet cells in $2 \mathrm{ml}$ eppendorf tubes

7. Wash the cell pellet with buffer 1

8. Discard the supernatant (you can stop the protocol at this step by freezing the pellets in liquid nitrogen and storage at $-80^{\circ} \mathrm{C}$.)

3.2 Spheroplast preparation

1. Cell pellets of $100 \mathrm{mg}$ are resuspended in $1 \mathrm{ml}$ of buffer 1 . Add 5,4 $\mu \mathrm{l}$ of 2mercaptoethanol $(14,3 \mathrm{M})$. Incubate in ice during $10 \mathrm{~min}$

2. Centrifuge at $4^{\circ} \mathrm{C}$ for $5 \mathrm{~min}$ at $3000 \mathrm{rpm}$ and discard the supernatant

3. Resuspend the pellet in $1 \mathrm{ml}$ of buffer 1 (without 2-mercaptoethanol). Add 600 $\mu \mathrm{g}$ of zymolyase $20 \mathrm{~T}$ (see note 2 )

4. Incubate with gentle agitation for $30 \mathrm{~min}$ at $35^{\circ} \mathrm{C}$

5. Add directly in the tube $700 \mu \mathrm{l}$ of buffer 2 containing a mixture of protease inhibitors (PI) (see Note 3)

6. Centrifuge $5 \mathrm{~min}$ at $4^{\circ} \mathrm{C}$ at $3500 \mathrm{rpm}$ and discard the supernatant (to discard any traces of zymolyase) 
7. Optional: add $2 \mathrm{ml}$ of buffer $2+$ PI without resuspension of the pellet and centrifuge at $4^{\circ} \mathrm{C}$ for 5 min at 3500rpm. Discard the supernatant

\subsection{Extraction}

All the following steps are to be performed on ice, unless otherwise indicated.

1. Resuspend the pellet in $700 \mu \mathrm{l}$ of buffer $3+\mathrm{PI}$. Incubate for $5 \mathrm{~min}$ on ice

2. Centrifuge for $5 \mathrm{~min}$ at $11000 \mathrm{rpm}$ at $4^{\circ} \mathrm{C}$ and discard the supernatant

3. Resuspend the pellet in $700 \mu \mathrm{l}$ of buffer 4 . Add IGEPAL ${ }^{\circledR}$ CA- 630 detergent to a final concentration of $0,5 \%$ and PI (see Note 4). Let in ice for $5 \mathrm{~min}$.

4. Centrifuge at $4^{\circ} \mathrm{C}$ for $5 \mathrm{~min}$ at $12000 \mathrm{rpmand}$ discard the supernatant

5. Resuspend the pellet in $700 \mu \mathrm{l}$ of buffer $4+\mathrm{PI}$ and let on ice for $5 \mathrm{~min}$.

6. Centrifuge at $4^{\circ} \mathrm{C}$ for $5 \mathrm{~min}$ at $13000 \mathrm{rpm}$, discard the supernatant

7. Add $120 \mu \mathrm{l}$ of $0,25 \mathrm{M} \mathrm{HCl}$

8. Place a small magnetic barrel in the tube and agitate for $2 \mathrm{~h}$ (minimum) at $4{ }^{\circ} \mathrm{C}(\mathrm{a}$ rotor wheel can be also used).

9. Centrifuge at $4^{\circ} \mathrm{C}$ for $15 \mathrm{~min}$ at $12000 \mathrm{rpm}$

10. Transfer the supernatant in a $15 \mathrm{ml}$ Falcon tube

11. Add 8 volumes of acetone for 1 volume of supernatant

12. Mix by inversion and place the tube overnight at $-20^{\circ} \mathrm{C}$

13. Centrifuge at room temperature for $10 \mathrm{~min}$ at $3500 \mathrm{rpm}$ and discard the supernatant

14. Resuspend the pellet with $400 \mu \mathrm{l}$ of acidified acetone and transfer the resuspended pellet in an $1.5 \mathrm{ml}$ tube.

15. Centrifuge at RT for $5 \mathrm{~min}$ at $10000 \mathrm{rpm}$. You should see a white visible pellet.

16. Discard the supernatant and add $1 \mathrm{ml}$ of acetone and carefully slowly vortex

17. Centrifuge at RT for $5 \mathrm{~min}$ at $10000 \mathrm{rpm}$ and discard the supernatant

18. Dry the pellet with a speed-vac (no more of $20 \mathrm{~min}$ ) or let it dry at $37^{\circ} \mathrm{C}(\mathrm{see}$ note 5)

19. Resuspend the pellet with $10 \mu \mathrm{l}$ of distilled water.

20. Add $5 \mu$ l of loading buffer $(2 \mathrm{X})$ to $5 \mu \mathrm{l}$ of purified histones. The remaining histone preparation can be kept at $-20^{\circ} \mathrm{C}$.

21. Denature for $5 \mathrm{~min}$ at $100^{\circ} \mathrm{C}$.

22. Load $2 \mu \mathrm{l}$ on a $16 \%$ SDS-PAGE (see note 6 ) and run at $100 \mathrm{~V}$ for $3 \mathrm{~h}$

\subsection{Coomassie Staining}

1. Stain the acrylamide gel in the Coomassie staining solution for $30 \mathrm{~min}$

2. Destain for one hour in the Coomassie destaining solution

(Figure 1)

\section{Notes}

1. W303 MATa $\{l e u 2-3,112$ trp1-1 can1-100 ura3-1 ade2-1 his3-11,15\} 
2. Do not add an excess of zymolyase, it may result in the clipping of the Nterminal tail of H3 (Santos-Rosa et al. 2009)

3. IGEPAL ${ }^{\circledR}$ CA-630 is a nonionic, non-denaturing detergent. Caution, it is a severe eye irritant.

4. Do not dry excessively the pellet

5. Wear a mask when weighing acrylamide. Unpolymerized acrylamide is a neurotoxin and care should be exercised to avoid skin contact.

\section{References}

Dehé, P.M., Pamblanco, M., Luciano, P., Lebrun, R., Moinier, D., Sendra, R., Verreault, A., Tordera, V., and Géli, V. (2005) Histone H3 lysine 4 monomethylation does not require ubiquitination of histone H2B. J Mol Biol. 353(3):477-84.

Poveda, A., Pamblanco, M., Tafrov, S., Tordera, V., Sternglanz, R. \& Sendra, R. (2004). Hif1 is a component of yeast histone acetyltransferase $B$, a complex mainly localized in the nucleus. J. Biol. Chem. 279, 16033-16043.

Santos-Rosa H., Kirmizis A., Nelson C., Bartke T., Saksouk N., Cote J., Kouzarides T. (2009). Histone H3 tail clipping regulates gene expression. Nat Struct Mol Biol. 16(1): 17-22.

Acknowledgments. We thank Vicente Tordera and Merce Pamblanco (University of Valencia) who showed us how to purify histones from $S$. cerevisiae.

Figure 1. Purification of histones visualized in a 16\% SDS-PAGE stained with Coomassie blue. The four histones are indicated. * represents a degradation band. 


\section{A}

$2 \mu \mathrm{l} \quad 5 \mu \mathrm{l}$

\section{$70 \mathrm{kDa}$ \\ $50 \mathrm{kDa}$ \\ $40 \mathrm{kDa}$ \\ $35 \mathrm{kDa}$ \\ $25 \mathrm{kDa}$}

$15 \mathrm{kDa}$

$\mathrm{H} 3$

H2B

$\mathrm{H} 2 \mathrm{~A}$

$*$

H4

$10 \mathrm{kDa}$ 